\title{
Implementing solar based renewable energy system on Shariatpur Polytechnic Institute and its impacts on Energy cost after renewable energy interconnection On institute's campus power network
}

\author{
${ }^{1 .}$ Sujan Kumar Talukdar , ${ }^{2 .}$ Rajib Bosu, ${ }^{3 .}$ Md. Abu Zahed \\ ${ }^{1}$ Instructor (Computer Technology). Shariatpur Polytechnic Institute, Bangladesh. \\ ${ }^{2}$ Instructor (Telecommunication Technology). Shariatpur Polytechnic Institute, Bangladesh. \\ ${ }^{3}$ Instructor (Computer Technology). Shariatpur Polytechnic Institute, Bangladesh.
}

\begin{abstract}
Bangladesh is underdeveloped country but the electricity problem is one of the main burdens of our economical growth. We know that technical education is an important opportunity to gain the millennium development. The government takes several steps to develop our technical education sector. Polytechnic education system is based on sound power supply. When power problem is presented then the student of polytechnic are basically affected, they do not attain their lesson attentively and regularly. Even they do not attain their laboratory works, complete their class notes. But there is a huge opportunity to back up the energy problem using solar energy. This paper implement and analysis of solar energy and cost analysis tell that the system is economically feasible for a polytechnic institute.
\end{abstract}

\section{Introduction}

It's better to teach a man to fish than given a man a fish. This analogy has often been described as the difference between charity and development work, it is also an interesting way of distinguishing between development and its future buzz phrase, sustainable development. Sustainable development is about making sure that people throughout the world can satisfy their basic needs now, while making sure that future generations can also look forward to same quality of life. It recognizes that there are three pillars the economy, society and the environment. The concept which is logical and holistic has been around for decades and is somewhat incorporate in the millennium development Goals which expire. For this reasons the total economical growth is hampered. The solution is must be needed to recover this condition. There is no enough generation of electrical energy to remain the demand and there is a shortage of raw material for producing the energy. Wind \& Hydro power have a limited scope of success in Bangladesh, but could solar \& biogas provides a viable solution to our existing energy problems.

Solar power is not new in Bangladesh. Since, 1996 different companies have tried to market solar energy systems to the public. Yet in a technologically backward country like Bangladesh the ides took a fair while to gestate. Solar and biogas energy is a renewable energy without causing pollution to the environment. Grameen Shakti and few other companies are working to provide solar biogas energy to the villages in Bangladesh. The Government of Bangladesh is working to provide more energy to its people to accelerate economic growth, social development and reduce poverty. On one hand, government is working to promote the use of renewable energy technologies. On the other hand, the government works with industry public sector power utilities and private households to increase the use of energy efficient appliance and production processes and promote energy generation. Renewable energy and energy efficiency is a priority area of Bangladeshi German development co-operation.

\section{Printed Works On Solar Energy}

In this portion, several important topics are discussed which appeared to us after the review of recent work Solar based power plant.

2.1 Solar energy: Solar electricity is the energy which is extracted by Sun using solar power plants. Sun is the richest source of energies like light and heat. Huge amount of energies are available for us to take and make big impact on our electricity requirements. Our sun throws as much amount of energy on earth in one day which is equivalent to the energy requirement for the entire year. 
Implementing solar based renewable energy system on Shariatpur Polytechnic Institute and its ..

23.2 Photovoltaic or solar cell: It is possible to convert solar energy directly into electrical energy by means of silicon wafer photovoltaic cells, also called solar cells, without any intermediate thermodynamic cycle. The solar cell operates operate on the principle of photovoltaic effect, which is a process of generating an emf as a result of the absorption of ionizing radiation. Thus a solar cell is a transducer, which converts the sun's radiant energy directly into electrical energy and is basically a semiconductor diode capable of developing a voltage of developing a voltage of $0.5-1$ volt and a current density of $20-40 \mathrm{Ma} / \mathrm{cm}$ depending on the materials used and the conditions of sunlight.

2.2.1 The efficiency of the solar cells and their maintenance: The photovoltaic effect can be observed in nature in a variety of materials having the best performance in sunlight is the semiconductors. In a piece of pure semiconductor like silicon, there is no free charge carrier at ordinary temperatures, but if this piece of silicon is doped with phosphorous or arsenic there will be one extra electron per atom of the impurity leading to $\mathrm{N}$ type(negative type) semiconductor. Similarly, if another piece of pure silicon is doped with boron (having one electron less than silicon) there will be deficiency of electrons (or excess of holes) leading to $\mathrm{P}$-type (positive type) semiconductor. If these two pieces of silicon containing $\mathrm{N}$ - type and P-type impurities are connected by some means, a junction, at which the nature of the current carrier changes, is created. In fact, a potential energy $\operatorname{gap}(\mathrm{Eg})$ is created at the junction.

When a photon of energy hv' is allowed to fall on the P- region, it is absorbed by an electron in the valance band .If hv' exceeds energy gap Eg, the electron will migrate to the N- region. Similarly if hv' is less than Eg in the $\mathrm{N}$ - region, the photon will be absorbed by a hole which will migrate to P-region. This charge separation creates an electric field opposite to the electric field created by the diffusion of free electrons of the $\mathrm{N}$ - region and in case the field created by charge separation predominates the electric field created by the diffusion of free electrons from $\mathrm{N}$ - region to P-region and holes from $\mathrm{P}$ - region to $\mathrm{N}$-region current will start flowing in the circuit, as shown in fig.

\section{Inside a Photovoltaic Solar Cell}

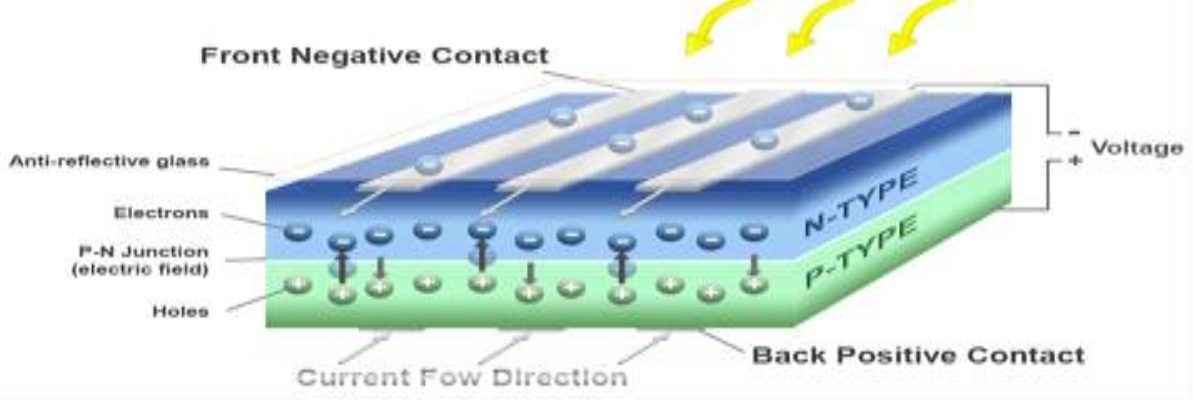

Figure 2.1: Photovoltaic or Solar cell

2.3 Roof top array system: This system is an earth based solar cell system mounted on roofs. The main difficulty is the problem of energy storage since this system will work when there is sunshine. The various possible alternatives for energy storage are:

(a) Electrochemical storage, but batteries of adequate capacity that can withstand frequent charging and discharging for several years are yet to be developed.

(b) Hydro storage in which water is pumped uphill when power is abundant and allowed to flow through generators at a time of peak demand. This possibility is suitable only to a few regions of the country.

(c) Mechanical storage in high speed flywheels.

(d) To store energy in the form of hydrogen, which could be re-converted into electricity in fuel cells. Hydrogen is obtained by the electrolysis of water by the output of the solar cells.

2.4 Storage device: The electricity produced by the PV modules is stored in batteries for later use when there is no sun. Deep-cycle batterinewes are used that provide electricity over long periods of time and can repeatedly charge and discharge up to $80 \%$ of their capacity.

2.5 Inverters: The inverter converts the DC electricity produced by the solar modules into alternating current (AC) since most electrical appliances and equipment run on AC electricity. It also conditions the electricity produced by adjusting the frequency of the AC cycle (50 or 60), preventing voltage fluctuation and improving the quality of the AC sine curve by making the jagged wave shape smoother.

DOI: 10.9790/1676-1104033441 $\quad$ www.iosrjournals.org $35 \mid$ Page




\section{Methodology}

Solar power is the conversion of sunlight into electricity, either directly using photovoltaic (PV), or indirectly using concentrated solar power (CSP). Concentrated solar power systems use lenses or mirrors and tracking systems to focus a large area of sunlight into a small beam. Photovoltaic convert light into electric current using the photoelectric effect.

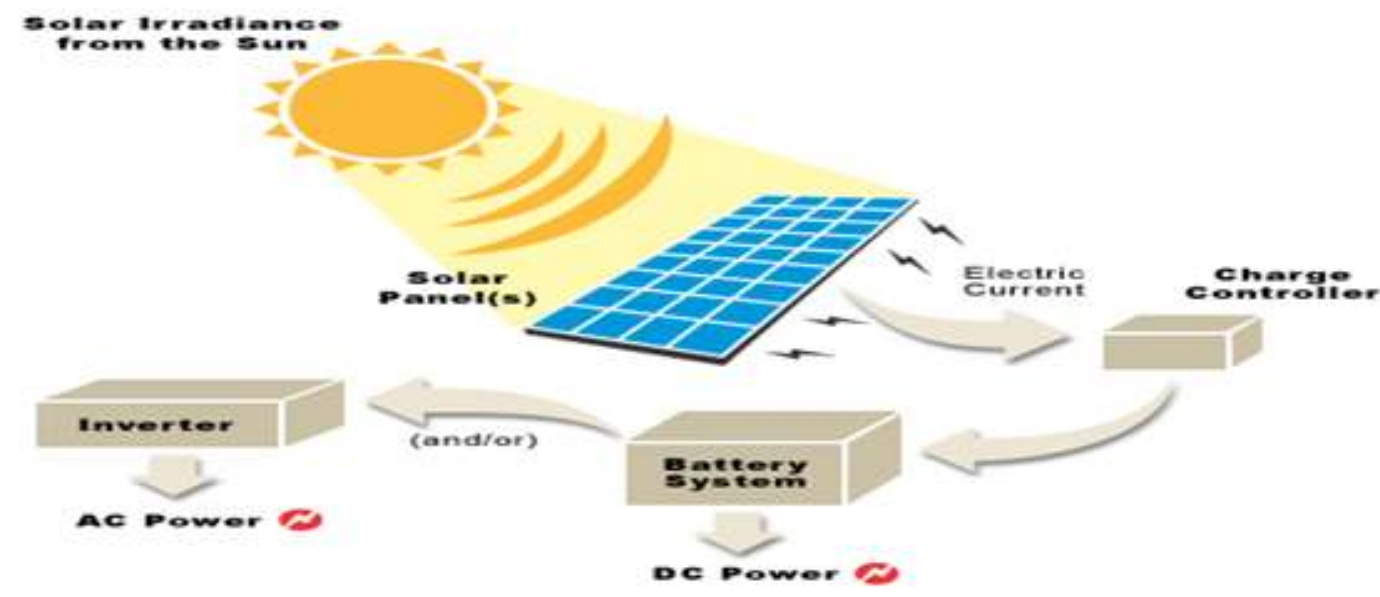

Figure 3.1: Solar energy generation method

\subsection{Potentials of solar energy depend on roof space:}

Solar power is a renewable resource. As long as the sun exists, its energy will reach earth. The power generation releases no water or air pollution, because there is no chemical reaction from the combustion of fuels. The energy can be used effectively for practical uses such as heating \& lighting. The benefits of solar power are seen frequently to hear pools, spas \& water tanks all over.

\section{A) POTENTIALS OF SOLAR ENERGY IN SHARIATPUR POLYTECNIC INSTITUTE}

The polytechnic institute is most reliable and sound place to put the PV array is on the roof of the building. The possibility of building for PV installation regarding roof orientation, roof size, roof inclination and module efficiency depends on some assumptions.

The formula used for the calculation of solar energy potential as follows:

$\mathrm{Y}=\mathrm{n} \times \mathrm{F} \times \mathrm{H} \times \mathrm{f}$, where,

$\eta=$ Efficiency factor of the PV system;

$\mathrm{F}=$ Suitable roof area $\left[\mathrm{m}^{2}\right]$;

$\mathrm{H}=$ Average annual global radiation on the installation location $\left[\mathrm{kWh} / \mathrm{m}^{2}\right]$;

$\mathrm{f}=$ Correction factor for the PV- system inclination and exposition.

A PV array will typically produce energy for 25 years or more, so choosing a roof that matches the lifecycle of the PV system makes the most economic sense.

Our institute is perfect to install PV panel and makes a sound recipient of solar energy. We recorded the variation of output power with respect to time. The output table is given below:

Observational Date: $20^{\text {th }}$ February 2016

\begin{tabular}{|l|l|l|l|l|}
\multicolumn{7}{l|}{ Table 1: PV Panel: } \\
\hline Reading no: & Voltage (V) & Current (A) & Power (W) & Time (Hours) \\
\hline 01. & 20 & 0.46 & 9.2 & 12.25 PM \\
\hline 02. & 20.13 & 0.49 & 9.8637 & 12.45 PM \\
\hline 03. & 20 & 0.495 & 9.9 & 01.05 PM \\
\hline 04. & 20.01 & 0.498 & 9.96498 & 01.25 PM \\
\hline 05. & 20 & 0.496 & 9.92 & 01.45 PM \\
\hline
\end{tabular}

\section{The 100 Watt Solar Panel And Its Specification Is As Follows:}

We are considering 100 watt solar panel with respect to area academic building, administrative building, two small two-storied building (Auditorium and Common room) and the residence of principal on institute.

Here, we find that,

Length, $1=3.36 \mathrm{ft}$ 
Width, $w=2.20 \mathrm{ft}$

Area $=$ Length $\times$ Width

$=3.36 \times 2.20=7.392$ square $\mathrm{ft}$.

Estimating of total roof space:

Academic building $=5000$ sq. $\mathrm{ft}$.

Administrative building $=5000$ sq. $\mathrm{ft}$.

First two-storied building (Auditorium) $=3300$ sq. ft.

Second two-storied building (Common Room) $=3300$ sq. $\mathrm{ft}$.

Residence of principal $=1100$ sq. $\mathrm{ft}$.

Now,

7.392 square ft. equal to $=100 \mathrm{Watt}$

So, 1 square ft. equal to $=(100 / 7.392) \mathrm{Watt}$

So, 5000 square ft. equal to $=(100 \times 5000) / 7.392 \mathrm{Watt}$

$=67.64$ Kilo-Watt

$=67 \mathrm{KW}$ (Approximately)

So, Total panel required in Administrative and Academic building $=(670+670)=1340$ pieces

(Because of each of the panel wattage is $100 \mathrm{Watt}$ )

Two-storied Building (Auditorium) $=3300$ sq. $\mathrm{ft}$.

So, 3300 square $\mathrm{ft}$. equal to $=(100 \times 3300) / 7.392 \mathrm{Watt}$

$=44.64$ Kilo-Watt

$=44 \mathrm{KW}$ (Approximately)

So, Total panel required in Two Storied Building (Auditorium and Common) $=(440+440)$ pieces (Because of each of the panel wattage is 100 Watt.)

\section{Factors Influencing Solar Feasibility}

The objective is to understand what factors influence rooftop solar feasibility and establish a guideline for designing solar ready roofs. Key roof factors that influence system performance include Orientation (Building \& module), Roof form (inclination, levels in roof and roof penetrations), Roof area \& shading (external shadows, shadow from building massing and roof equipments).

\section{i) Orientation:}

If a building with sloped roofs is designed, it is best to orient the building to get maximum southern exposure (northern exposure in the southern hemisphere). In a building when flats roofs PV panels are arranged in sloped surface towards south. Placement of PV panels on the south-facing slope will ensure that the sunlight strikes the solar collectors at a more optimal angle than it would if the collectors are placed on the east, west or north-facing roof sections. The pitch of the east west orientation of the roof. These effects are summarized in Table 3.

Solar PV will produce the most energy when they are aligned at an angle equal to the latitude where it is located.

Table 6.2: Orientation factors for various roof pitches and directions

\begin{tabular}{|l|l|l|l|l|l|l|}
\hline Directions & Flat $\left(0^{0}\right)$ & $15^{0}$ & $30^{0}$ & $45^{0}$ & $60^{0}$ & $90^{0}$ \\
\hline S & 0.89 & 0.97 & 1.00 & 0.97 & 0.89 & 0.58 \\
\hline SSE,SSW & 0.89 & 0.97 & 0.99 & 0.96 & 0.88 & 0.59 \\
\hline SE,SW & 0.89 & 0.9 & 0.96 & 0.93 & 0.85 & 0.60 \\
\hline ESE,WSW & 0.89 & 0.92 & 0.91 & 0.87 & 0.79 & 0.57 \\
\hline EW & 0.89 & 0.88 & 0.84 & 0.78 & 0.70 & 0.52 \\
\hline
\end{tabular}

\section{ii) Roof Area:}

The amount of roof space needed to mount a solar system is based on the size or, generating capacity or rating of the system. From Table 4 it can be stated that, the efficiency varied with different types of PV modules, higher efficiency modules typically cost more. Most residential systems require as little as $50 \mathrm{ft}^{2}$ of mounting area for a small starter system or as much as $500-1000 \mathrm{ft}^{2}$ for a PV array. A rule of thumb is that a square foot of single PV module area produces 10 watts a of power in bright sunlight. Therefore, a 1000 watt system requires about 100 to $200 \mathrm{ft}^{2}$ of roof area, depending on types of PV module. Table 4 provides approximately roof area requirements as a function of PV efficiency \& rating.

Table 6.3: Roof Area Needed for Variable sizes of PV System

\begin{tabular}{|l|l|l|l|l|l|l|l|l|}
\hline PV Module Efficiency & & PV & Capacity & Rating & (Watts) & & \\
\hline (In Degree) & 200 & 500 & 1000 & 2000 & 4000 & 10000 & 1000000 \\
\hline AREA IN FT $^{2}$ & 30 & 38 & 75 & 150 & 300 & 6000 & 15000 \\
\hline 4 & 15 & 25 & 50 & 100 & 200 & 400 & 15000 \\
\hline 8 & 10 & 20 & 40 & 80 & 160 & 320 & 8000 \\
\hline 12 & 8 & 75 & 150 & 300 & 600 & 1200 & 3000 \\
\hline 16 &
\end{tabular}


Implementing solar based renewable energy system on Shariatpur Polytechnic Institute and its ..

\section{iii) Roof Form:}

Roof inclination, covering materials \& penetrations impact the suitability for PV. Large, flat \& unobstructed roofs offer the most flexibility to install PV in a manner that optimizes performance. PV can be installed on pitched roofs, but may raise aesthetic concerns from neighbors. CAL FIRE OSDM (2008) recommends that no more than 50\% of a steep sloped roof area be covered with PV panels. Finally, while most roof penetrations such as skylights or plumbing vents can be worked around, such elements can cast shadow and will impact panel layout. Due to these types of roof penetration, excessive irregularities in the geometry can limit the system's performance. It is usually a good roof design practice to minimize as many roof penetrations as possible.

\section{iv) Shading:}

Shading has more impact on solar PV efficiency than orientation or inclinations. Shading reduces power output and creates thermal stress on the module. Partial shading of even one cell of a PV module will lower the string voltage and can reduce power output. Shading of even one cell within a PV module can reduce the module's power output by as much as $75 \%$. Shadows across PV modules can be cast by adjacent building, trees or onsite obstacles such as parameter Architecture elements of building such as HVDC equipments or satellite dishes can also create shaded areas.

\section{Study Of Existing Institute Load Curve:}

According to the demand of power we have separated the total generation on the basis of renewable energy. The demand of electricity is varying with respect to time. When we required a huge amount of power then connects the required energy with respect to some units (Renewable energy). We are maintaining the total generation and BPDB supply by using control unit and substation. With respect to renewable energy source and BPDB we can fulfill the total demand of institute campus.

B) Table 11.1: Identifying Important Loads:

\begin{tabular}{|c|c|c|c|c|c|c|c|c|}
\hline Building Name & $\begin{array}{l}\text { Load } \\
\text { (Emergency) } \\
\text { KW }\end{array}$ & $\begin{array}{l}\text { Quantity } \\
\text { of Light }\end{array}$ & $\begin{array}{l}\text { Rating per } \\
\text { light (Watt) }\end{array}$ & $\begin{array}{l}\text { Quantity } \\
\text { of Fan }\end{array}$ & $\begin{array}{l}\text { Rating of } \\
\text { Fan (Watt) }\end{array}$ & $\begin{array}{l}\text { Quantity } \\
\text { of Pc }\end{array}$ & $\begin{array}{l}\text { Rating } \\
\text { per PC } \\
\text { (Watt) }\end{array}$ & $\begin{array}{l}\text { Lab } \\
\text { Machinery } \\
(\mathrm{KW})\end{array}$ \\
\hline $\begin{array}{l}\text { Academic } \\
\text { Building }\end{array}$ & 29.35 & 165 & 60 & 115 & 90 & 30 & 270 & 1 \\
\hline $\begin{array}{l}\text { Administrative } \\
\text { Building }\end{array}$ & 33.98 & 93 & 60 & 60 & 90 & 18 & 270 & 1 \\
\hline $\begin{array}{l}1^{\text {st }} \text { Two storied } \\
\text { Building }\end{array}$ & 7.48 & 50 & 60 & 27 & 90 & 4 & 270 & 1 \\
\hline $\begin{array}{l}2^{\text {nd }} \text { Two storied } \\
\text { Building }\end{array}$ & 8.02 & 48 & 60 & 34 & 90 & 4 & 270 & 1 \\
\hline Server & 10 & & & & & & & \\
\hline
\end{tabular}

\section{C) Distribution of Loads:}

$>$ Load A: Teacher's Chambers $(9)=[34($ Light $)+17($ Fan $)+11(\mathrm{PC})]=6.54 \mathrm{KW}$

$>$ Load B: Principal's Office $=[24($ Light $)+15($ Fan $) 3(\mathrm{PC})]=3.6 \mathrm{KW}$

$>$ Load C: Server $=10 \mathrm{KW}$

$>$ Load D: Classroom $(25)=[(165($ Light $)+115($ Fan $)+30($ PC $)+$ Machinery $(1 \mathrm{KW})]=29.35 \mathrm{KW}$

$>$ Load E: Principal's Resident : [16 (Light)+6(Fan)+1(PC)+1(Television)+1(Refrigerator)]

\section{Based on priority:}

$$
=2.42 \mathrm{KW}
$$

Table 11.2: Time duration table:

\begin{tabular}{|l|l|l|l|l|l|}
\hline Time of day & $00: 00-06: 00$ & $06: 00-07: 00$ & $07: 00-19: 00$ & $19: 00-20: 00$ & $20: 00-24: 00$ \\
\hline \multirow{3}{*}{$\begin{array}{l}\text { Running } \\
\text { Load }\end{array}$} & & & Load A & & \\
\cline { 2 - 6 } & & Load B & Load B & Load B & \\
\cline { 2 - 6 } & Load C & Load C & Load C & Load C & Load C \\
\cline { 2 - 6 } & & & Load D & & \\
\cline { 2 - 6 } & Load E & Load E & Load E & Load E & Load E \\
\hline Total Load (KW) & $12.42 \mathrm{KW}$ & $16.02 \mathrm{KW}$ & $51.91 \mathrm{KW}$ & $16.02 \mathrm{KW}$ & $12.42 \mathrm{KW}$ \\
\hline
\end{tabular}


II. Distribution of Renewable Energy:

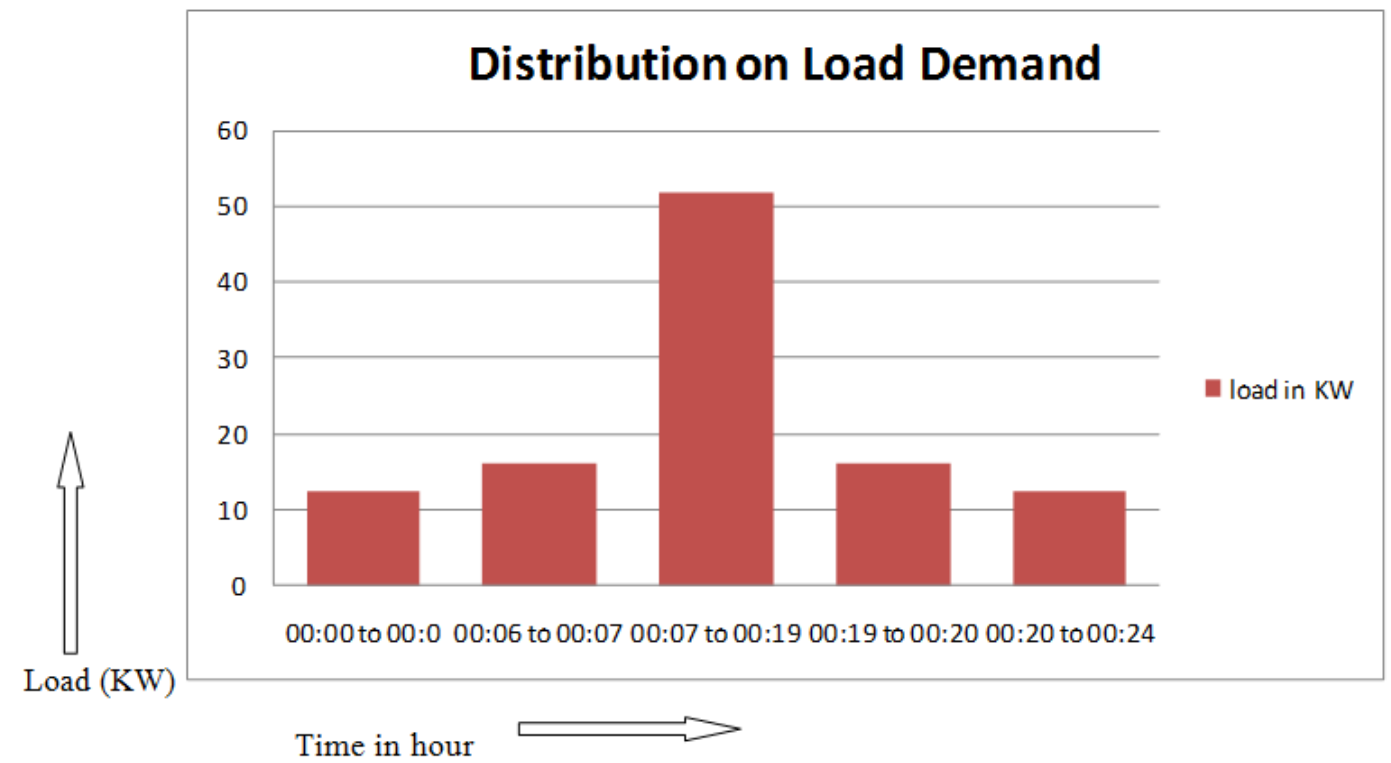

Fig11.1: Distribution on Load Demand.

\section{Cost Analysis:}

From the time duration table:

In time (00:00-06:00), the total load $=12.42 \mathrm{KW}$

Total time $=6$ hours

Total KW= $12.42 \times 6=74.52 \mathrm{KWh}$

$1 \mathrm{KWh}=1 \mathrm{Unit}$

1 Unit $=5$ Taka

$74.42 \mathrm{KWh}=74.42 \times 5=372.1$ Taka

For 1 day $=372.1$ Taka

$\Rightarrow 30$ day $=372.1 \times 30=11163$ Taka

From the time duration table:

In time (06:00-07:00), the total load $=16.02 \mathrm{KW}$

Total time $=1$ hours

Total KW= $16.02 \times 1=16.02 \mathrm{KWh}$

$1 \mathrm{KWh}=1 \mathrm{Unit}$

1 Unit $=5$ Taka

$16.02 \mathrm{KWh}=16.02 \times 5=80.1$ Taka

For 1 day $=80.1$ Taka

$\Rightarrow 30$ day $=80.1 \times 30=2403$ Taka

From the time duration table:

In time (07:00-19:00), the total load $=51.91 \mathrm{KW}$

Total time $=12$ hours

Total KW= $51.91 \times 12=622.92 \mathrm{KWh}$

$1 \mathrm{KWh}=1 \mathrm{Unit}$

1 Unit $=5$ Taka

$622.92 \mathrm{KWh}=5 \times 622.92=3114.6$ Taka

For 1 day=3114.6 Taka

$\Rightarrow 30$ day $=3114.6 \times 30=93438$ Taka

From the time duration table:

In time (19:00-20:00), the total load $=16.02 \mathrm{KW}$

Total time $=1$ hours

Total KW= $16.02 \times 1=16.02 \mathrm{KWh}$

$1 \mathrm{KWh}=1 \mathrm{Unit}$

1 Unit $=5$ Taka 


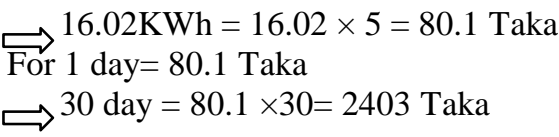

From the time duration table:

In time (20:00-24:00), the total load $=12.42 \mathrm{KW}$

Total time $=4$ hours

Total KW= $12.42 \times 4=49.68 \mathrm{KWh}$

$1 \mathrm{KWh}=1 \mathrm{Unit}$

1 Unit $=5$ Taka

$\Rightarrow 49.68 \mathrm{KWh}=49.68 \times 5=248.4 \mathrm{Taka}$

For 1 day $=248.4$ Taka

$\rightarrow 30$ day $=248.4 \times 30=7452$ Taka

Total per month savings $=11163+2403+93438+2403+7452=116859$ Taka.

\section{H) Cost analysis curve:}

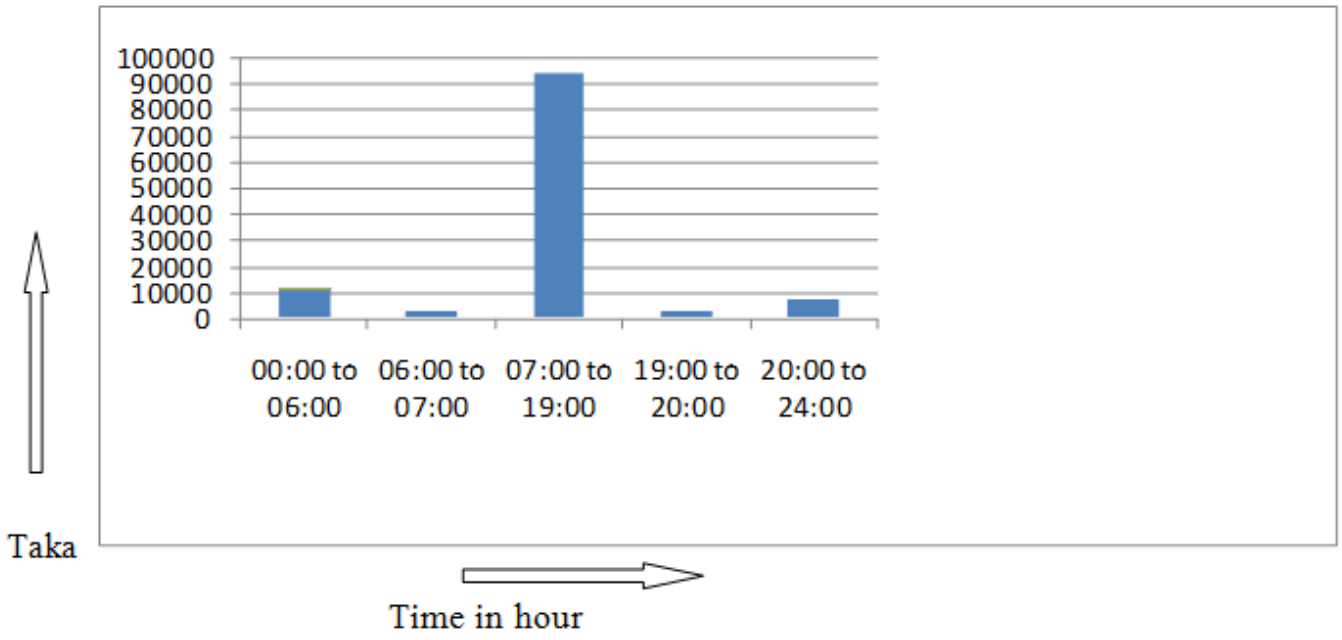

Fig 13.2: Cost analysis curve

\section{Conclusion}

Bangladesh has a great opportunity to generate solar with the help of sun shine. This renewable energy sources can be used for generating electricity and removing electrification problems in Bangladesh. As the electrification problems may not be removed in near future, this is the best alternative source to generate electricity. Our paper represents the alternate source at a Polytechnic institute according to solar based sunshine. To remove power problem, our represented paper can be used as an ideal model for every polytechnic institute in Bangladesh.

\section{Future Work}

We will investigate how to interconnect solar generation with grid system, reliability and system failure and management of load. We will plan and design for this new concepts to our institute not only to save cost but also reliable electric supply. So our works objectives not only focus for one institute but also community based power generation as well as development of our country through green energy.

\section{References}

[1]. Md. Nawrose Fatema, "Solar ready roof design for high performing solar installation in Dhaka: Potentials and strategies" $-2^{\text {nd }}$ International Conference on the developments in renewable energy technology, (ICDRET'12), January 5-7, 2012, Dhaka, Bangladesh, pp (235-238)

[2]. Available: http://www.smsolar.net/files/SM100.pdf

[3]. Available: http://en.wikipedia.org/wiki/Solar_power

[4]. Country report Bangladesh, Rabobank Economic Research Department, Jan. 2011.

[5]. [Online: March 2013] Wikipedia, http://en.wikipedia.org/wiki/Uninterruptible_power_supply

[6]. Tahsin Faraz, "Benefits of concentrating solar power over solar photovoltaic for power generation in Bangladesh" - $2^{\text {nd }}$ International Conference on the developments in renewable energy technology, (ICDRET'12), January 5-7,2012, Dhaka, Bangladesh, pp (183-187).

[7]. "Bangladesh: country profile", The Economist Intelligence Unit (EIU), London, 2008

[8]. EIA, "Bangladesh: country analysis briefs", Energy Information Administration, Washington DC, 2010 
Implementing solar based renewable energy system on Shariatpur Polytechnic Institute and its ..

[9]. M. E. Haq, “Bangladesh's Power Sector: Investment Opportunities,” Ministry of Power, Energy \& Mineral Resources, Bangladesh, Presented in London, Mar. 2011.

[10]. "Bangladesh Energy Crisis: Soul Searching," Energy Bangladesh, (2011, March). URL:http://www.energybangla.com/index. php? mod $=$ article $\&$ cat $=$ SomethingtoSay \&article $=2051$

[11]. Ahmed uddin, Hassn al "Traditional energy sources of Bangladesh" BEDC, 2008

[12]. Rafique,S., "Potential Sources of Energies in Bangladesh: Utilization And Environmental Issues", WREC VII , 2002

[13]. Available:http://bd.bpdb.gov.bd/download/tariff/Tariff\%20order.retail_9.1.2015.pdf 